\title{
Pengembangan kawasan pesisir melalui pembentukan Desa Wisata Sepahat Kabupaten Bengkalis
}

\author{
Syamsudhuha, Arisman Adnan, Afrianto Daud, Iswadi HR, Mirza Hardian, Nurhayati, Yennita \\ Roza, \& Ahmad Jamaan* \\ Universitas Riau \\ *ahmad.jamaan@lecturer.unri.ac.id
}

\begin{abstract}
Abstrak. Tulisan ini bertujuan mengembangkan potensi wisata Desa Sepahat, Kecamatan Bandar Laksamana, Kabupaten Bengkalis, apa saja yang telah dilakukan, kendala yang dihadapi, serta upaya pembinaan dilakukan guna mendukung terwujudnya desa wisata, serta rekomendasi kebijakan di masa datang. Kegiatan pengabdian ini menggunakan beberapa metode yaitu FGD, konsultasi, pendampingan, dan pelatihan. Focus Group Discussion (FGD) dilakukan antara tim pendamping (pengabdian masyarakat) dengan tim ahli lintas ilmu dan lintas perguruan tinggi yang peduli dan berpengalaman dalam mengembangkan dan mendampingi desa binaan dan desa wisata. FGD juga dilakukan bersama kepala desa dan tokoh masyarakat setempat. Konsultasi dilakukan antara pelaku usaha setempat, kepala desa dan tim pengabdian masyarakat. Pendampingan dilakukan antara pelaku usaha terkait langsung atau sebagai penunjang dengan kegiatan wisata dan dengan kelompok sadar wisata desa setempat. Hasil kegiatan ini adalah, tergalinya potensi ekonomi baru dalam mengembangkan desa wisata menambah potensi yang telah ada di pesisir pantai bertanah gambut, teridentifikasi sejumlah kegiatan mendorong terwujudnya desa wisata, adanya partisipasi aktif serta dukungan kuat dari masyarakat dan aparat setempat, juga diterimanya sejumlah usulan kebijakan untuk penguatan kelembagaan desa wisata.
\end{abstract}

Kata kunci: desa wisata, Desa Sepahat, partisipasi aktif masyarakat

\begin{abstract}
This paper aimed to develop the tourism potential of Sepahat Village, Bandar Laksamana District, Bengkalis Regency, what has been carried out, the obstacles are faced, and guidance efforts are carried out to support the realization of a tourist village, as well as recommendations that can be undertaken in the future. This community service activity used several methods, namely FGD, consultation, mentoring, and training. Focus Group Discussion (FGD) was conducted between the companion team (community service) with a team of cross-disciplinary and cross-university experts who were concerned and experienced in developing and assisting the fostered village and tourism village. FGD was also undertaken with the village head and local community leader. Consultation was carried out between local business actors, village head and community service team. Assistance was carried out between business actors directly related or as a support to tourism activities with local groups. The exploration of new economic potential in developing tourist villages, adding to the existing potential on the coast with peat soil, identifying a number of activities to encourage the realization of tourism villages, active participation and strong support from the society and local officials, gathering of society in tourism awareness groups, and also received a number of policy proposals to strengthen tourism village institutions.
\end{abstract}

Keywords: tourism village, Sepahat village, active society participation

To cite this article: Syamsudhuha., A. Adnan., A. Daud., Iswadi HR., M. Hardian., Nurhayati., Y. Roza., \& A. Jamaan. 2020. Pengembangan kawasan pesisir melalui pembentukan Desa Wisata Sepahat Kabupaten Bengkalis. Unri Conference Series: Community Engagement 2: 292-297. https://doi.org/10.31258/unricsce.2.292-297

(C) 2020 Authors

Peer-review under responsibility of the organizing committee of Seminar Nasional Pemberdayaan Masyarakat 2020 


\section{PENDAHULUAN}

Desa Sepahat merupakan salah satu desa di kabupaten Bengkalis yang berada di kawasan pesisir. Pada umumnya kawasan pesisir mempunyai sumberdaya perikanan dan sumberdaya hayati (biodiversity) seperti kawasan pesisir pada umumnya. Letak geografis desa sepahat yang berbatasan langsung dengan Selat Malaka menghadapi masalah seperti di berbagai kawasan pesisir lainnya yaitu abrasi sehingga harus menjadi perhatian pemerintah desa untuk menentukan langkah antisipasi terhadap fenomena alam seperti ini. Sebagai salah satu desa yang berada di kawasan pesisir di Kabupaten Bengkalis, Desa Sepahat secara geografis berhadapan langsung dengan Selat Malaka di bagian utara dengan komoditas unggulan berupa kelapa sawit, kelapa dan hasil tangkapan laut tradisional dengan luas wilayah sebesar 25.500 Ha.

Potensi lain Desa Sepahat yakni memiliki modal sosial sangat baik untuk dikembangkan untuk menjadi desa yang mandiri dengan menjadikan masyarakat sebagai basis utama dari kegiatan ekonomi. Mengacu pada Permendagri nomor 81 tahun 2015 tentang Tata Kelola Pemerintahan Desa, Sepahat menjadi desa terbaik I pada tahun 2019 dengan kriteria efektivitas penyelenggaraan pemerintahan, pembangunan, pemberdayaan dan pembinaan masyarakat. Keunggulan lain dari Desa Sepahat adalah ekosistem dan sumber daya alam yang baik untuk dapat dikembangkan menjadi produk lokal unggulan seperti pengembangan kawasan pesisir secara terpadu. Terpadu antara apa yang dijadikan misi pemerintah desa dengan aktivitas keseharian masyarakat terutama yang berbasis ekonomi tradisional dan ekonomi kreatif. Kegiatan ini pengabdian ini merupakan aktivitas yang sejalan dengan upaya pemerintah desa yang menitikberatkan gabungan potensi ekosistem kawasan pesisir menjadi pemberdayaan sumber daya manusia untuk menghasilkan kegiatan ekonomi masyarakat lokal yang diharapkan mampu menggerakkan ekonomi desa secara mandiri.

Kawasan pesisir merupakan salah satu destinasi yang tepat untuk dikembangkan dalam konsep pariwisata yang berkelanjutan berbasiskan masyarakat. Pariwisata merupakan model industri baru yang dapat memacu pertumbuhan ekonomi yang relatif cepat di sebuah daerah. Tersedianya lapangan kerja, pertumbuhan industri kreatif berbasis rumah tangga merupakan bagian kecil dari dampak positif yang akan muncul pada saat potensi daerah dikembangkan menjadi lokasi pariwisata yang dikelola secara mandiri oleh masyarakat setempat (Setiawan \& Zulfanita, 2016).

Konsep pariwisata dengan memberdayakan masyarakat juga merupakan salah satu cara yang paling efektif untuk menjadikan sebuah daerah menjadi kawasan wisata yang berkelanjutan. Peran masyarakat untuk membangun konsep kawasan pariwisata yang dikelola langsung masyarakat tempatan menuntut adanya perencanaan secara terpadu diiringi pendampingan terhadap tujuan pengembangan kawasan pariwisata sehingga manfaatnya dapat dirasakan langsung masyarakat setempat (Fildzah et al., 2015). Hanya saja selama ini pengembangan kawasan wisata cenderung dinikmati hanya oleh investor yang memiliki modal besar. Akibatnya masyarakat tempat kawasan dikembangkan hanya berperan kecil dari kegiatan ekonomi, hanya menjadi objek apalagi menjadi pelaku utama.

Diperlukan upaya menjadikan masyarakat sebagai pelaku utama kegiatan ekonomi berbasis pariwisata terutama di pedesaan. Pembentukan desa wisata terutama di kawasan yang memiliki potensi untuk dijual dan dikembangkan menjadi keniscayaan dan salah satu pilihan untuk melibatkan partisipasi aktif masyarakat. Desa wisata telah menjadi aktivitas ekonomi yang banyak membantu kesejahteraan masyarakat tempatan di berbagai kawasan dunia. Bahkan mampu menjadikan desa tersebut sebagai daerah mandiri dan maju.

Kendala yang dihadapi sebagian besar masyarakat di daerah berpotensi besar untuk dikembangkan sebagai destinasi wisata adalah kesadaran membaca dan memanfaatkan potensi dan menjadikannya sebagai peluang, rendahnya kemampuan SDM, tidak terlembaganya aktivitas masyarakat dalam wilayah pariwisata, serta belum optimalnya pemanfaatan sarana teknologi dalam memasarkan kawasan wisata tersebut. Di sisi lain, ketidaksatuan antara keinginan aparat pemerintah desa dalam pengembangan kawasan wisata dengan keinginan masyarakat bisa menjadi salah satu penghalang lainnya, seperti di Desa Sepahat.

Desa ini memiliki posisi strategis, sebagai daerah lintas dari Bengkalis ke Dumai, memiliki pantai yang indah didukung dermaga tempat pengunjung mudah mengakses pantai. Desa ini pun memiliki kerjasama secara tradisional dengan salah satu desa di Johor, Malaysia, terutama dalam kegiatan saling mengunjungi tempat masing-masing. Akan tetapi, berdasarkan hasil observasi di Desa Sepahat ini ada ada sejumlah faktorfaktor yang diidentifikasi dapat menjadi kendala pengembangan kawasan desa wisata. Pertama pengetahuan masyarakat yang belum mampu untuk menggali potensi dan menjadikan peluang wisata terutama pantai menjadi kegiatan keseharian (pekerjaan utama). Kedua, terkait dengan kapasitas masyarakat untuk melakukan aktivitas berbasis pariwisata. Ini berkait erat dengan karakter dan budaya masyarakat yang belum terbiasa dengan aktivitas melayani pendatang untuk mengunjungi tempat-tempat wisata secara menyeluruh. Ketiga, 
berhubungan dengan jejaring yang akan mendorong aktivitas pariwisata menjadi kegiatan bersama, terpadu sejalan dengan visi pemerintah desa setempat yang berazam untuk menjadikan desanya sebagai destinasi wisata. Keempat berkaitan dengan aspek permodalan.

Model pengembangan desa wisata pada umumnya dikembangkan berdasarkan pada tema kuliner, tema alam, tema pertanian, tema perkebunan, tema buah-buahan, tema sejarah, atau kombinasi dari potensi daerah yang dimiliki. Pengembangan wisata dengan memanfaatkan potensi desa merupakan salah satu upaya untuk meningkatkan peran masyarakat untuk pengembangan desa yang nantinya akan berdampak pada peningkatan kegiatan ekonomi masyarakat sekitar. Konsep pemberdayaan masyarakat dalam pengembangan desa wisata menjadi pilar dalam proses pembangunan desa, hal ini disebabkan daerah wisata akan menggerakkan kegiatan ekonomi seperti menciptakan peluang kerja baru, meningkatkan pendapatan ekonomi masyarakat lokal, retribusi, paja (Hermawan, 2017) serta memberikan dampak positif terhadap konservasi sumberdaya alam dan melestarikan budaya lokal sehingga terjadinya keseimbangan dalam proses pembangunan daerah setempat (Sayung \& Demak, 2015). Untuk mewujudkan pengembangan desa wisata yang optimal, maka pemerintah daerah juga harus mengambil peran dan melakukan kerjasama dengan masyarakat untuk pengembangan daerah wisata yang berkelanjutan.

Adapun untuk menciptakan konsep pariwisata yang berkelanjutan melalui pengembangan desa wisata harus memperhatikan prinsip (1) keseimbangan yang didasarkan pada komitmen pola keseimbangan antara pembangunan ekonomi, sosial budaya dan konservasi, (2) adanya partisipasi masyarakat, (3) adanya konservasi sebagai pertanggungjawaban komitmen pengambangan kawasan pesisir terhadap kaidah-kaidah ekologi, (4) keterpaduan dengan memperhatikan sinergi antara kondisi ekosistem dengan konsep pembangunan di kawasan pesisir, dan (5) pengembangan kawasan pesisir untuk pariwisata harus sesuai dengan aturan yang berlaku (Binilang, 2018).

Kegiatan pengabdian ini akan difokuskan kepada aktivitas penyadaran dan pemberdayaan masyarakat dalam mengoptimalisasi kawasan pantai sebagai destinasi wisata. Pendampingan berupa membangun kesadaran dari masyarakat setempat untuk mengubah kebiasaan dan cara pandang masyarakat yang berada di Desa Sepahat Kabupaten Bengkalis terhadap aktivitas wisata serta penguatan kapasitas institusi. Desa yang berada di kawasan pesisir pantai dan berbatasan langsung dengan Selat Melaka ini memiliki pantai wisata yang berpotensi untuk dikembangkan. Akan tetapi kegiatan wisata di desa ini belum menjadi aktivitas yang bersebati dengan aktivitas masyarakat tempatan. Mayoritas masyarakatnya cenderung bergantung pada dua aktivitas ekonomi, perkebunan sawit-karet dan perikanan.

\section{METODE PENERAPAN}

Ada tiga metode yang digunakan dalam pendampingan pembentukan Desa Wisata Sepahat ini yaitu FGD, pendampingan dan pelatihan serta penguatan institusi. Pertama, Focus Group Discussion (FGD) dilakukan dengan pakar dari berbagai universitas (UI, ITB, IPB, USU, dan Unila) yang memiliki pengalaman dan keberhasilan dalam pendampingan kawasan wisata di Indonesia. Kegiatan ini untuk mengumpulkan aspek apa saja yang dapat mendukung pembentukan desa wisata, apa saja faktor penghalang serta upaya dan jalan keluar untuk menyelesaikan hambatan yang muncul. FGD kedua dilakukan dengan kepala Desa Sepahat dengan tujuan untuk mengidentifikasi kondisi apa yang terjadi di wilayah pemerintahan, upaya yang sudah dilakukan serta rekomendasi pendampingan yang dapat dilakukan.

Kedua, pendampingan dan pelatihan. Kedua aktivitas ini dilaksanakan dengan tujuan mengukur pemahaman masyarakat desa terkait dengan desa wisata, pelatihan wawasan kewirausahaan serta pentingnya sinergitas antara aparat pemerintah dan masyarakat dalam mengembangkan kawasan wisata. Melalui kegiatan ini akan dilihat bagaimana respon peserta pelatihan serta partisipasi mereka dalam mengembangkan desa wisata. Keberhasilan kegiatan ini akan diukur melalui angket yang disebar kepada peserta pasca pendampingan dilakukan.

Ketiga, penguatan institusi/kelembagaan masyarakat dan pemerintah desa terkait kesiapan dan komitmen untuk mengembangkan desa mereka sebagai desa wisata. Ketercapaian kegiatan ini akan dilihat dari dibentuknya kelompok sadar wisata (Pokdarwis), penguatan institusi melalui ketersediaan aturan kelembagaan baik di tingkat Pokdarwis berbentuk struktur organisasi, penyediaan dan pembahasan anggaran dasar lembaga, ketersediaan rancangan peraturan desa (Perdes) tentang Desa Wisata Sepahat, serta dukungan aparat pemerintah desa dan pemerintahan di tingkat lebih tinggi (kecamatan). 


\section{HASIL DAN KETERCAPAIAN SASARAN}

Kegiatan Focus Group Discussion (FGD) dilakukan secara Daring dengan sejumlah pakar dan praktisi yang telah berpengalaman dan keberhasilan mendampingi masyarakat di daerah yang beragam. Ada yang memiliki potensi pertanian, perairan dan perikanan, perkebunan serta laut, juga hutan mangrove. Persoalan pengetahuan, kesadaran dan kualitas sumber daya manusia merupakan faktor yang sering muncul dalam membangun sebuah budaya baru seperti ekonomi wisata. Keberlanjutan pendampingan dan partisipasi aktif masyarakat menjadi dua faktor keberhasilan terbangunnya desa wisata. Perubahan sikap, cara pandang dan kebiasaan masyarakat terhadap potensi yang dimiliki desanya menjadi bagian tak terpisahkan dari partisipasi aktif warga di mana kegiatan pariwisata dikembangkan sebagai aktivitas baru.

Ada sejumlah sumbang saran dari kegiatan ini untuk diterapkan di Desa Sepahat, yaitu melakukan kegiatan jangka panjang termasuk koordinasi dengan pemerintah kabupaten agar melakukan kegiatan investasi dalam bentuk pembangunan layanan fasilitas umum yang menunjang Desa Sepahat sebagai desa wisata. Masyarakat desa ini juga harus menjual dan mempromosikan ciri khas yang dimilikinya. Aktivitas branding ini dilakukan beriringan dengan menampilkan berbagai karya produk ekonomi kreatif masyarakat tempatan hasil kreasi UMKM secara secara mandiri.

FGD kedua yang dilakukan bersama kepala Desa Sepahat dilakukan secara Daring dan Luring. Dari pertemuan ini dapat diidentifikasikan apa potensi yang dapat dikembangkan di desa sebagai penunjang kegiatan pariwisata, apa saja yang telah dilakukan, apa saja kendala yang dihadapi serta peluang dan alternatif keluar dari masalah yang ada. Selain potensi wisata pantai, desa juga memiliki potensi wisata memancing, wisata melaut dan kegiatan permainan laut. Dari kegiatan ini terungkap bahwa Desa Sepahat telah memiliki kerjasama dengan kawasan desa di Johor, Malaysia (sister village), akan tetapi aktivitas yang dilakukan masih sederhana dalam bentuk kunjungan sosial dan budaya. Oleh karena di desa ini tidak ada penginapan, maka sejumlah keluarga (10 keluarga) juga telah menyediakan kamar-kamar di rumahnya yang akan dijadikan sebagai homestay. Bila tamu datang dari berbagai tempat, maka kamar-kamar tadi disewakan dengan konsep hidup bersama pemilik rumah. Pengunjung di desa akan merasakan sensasi tinggal di rumah perkampungan yang sederhana dengan perlengkapan seadanya termasuk aktivitas di kamar mandi, makan dan sarapan bersama.

Persoalan yang terungkap adalah belum kuatnya dukungan masyarakat terhadap upaya pemerintah desa untuk membangun tradisi baru berupa aktivitas pariwisata. Padahal investasi yang telah dikeluarkan pemerintah desa untuk memoles desa sebagai tujuan kunjungan wisata terutama kawasan pantai mendekati nilai Rp 1 miliar. Cara-cara penyadaran, meningkatkan pemahaman, kepedulian serta dukungan dan komitmen masyarakat melalui pendampingan menjadi cara untuk menyelesaikan persoalan ini.

Kedua, pelatihan dan pendampingan secara bersamaan. Pelatihan dilakukan untuk masyarakat desa, pelaku UMKM, pengelola Badan Usaha Milik Desa (Bumdes) serta warga yang menyediakan kamar sebagai home stay. Ada sejumlah pelatihan yang diberikan kepada masyarakat setempat. Terkait dengan kemandirian ekonomi desa melalui pengembangan desa wisata, pelatihan kewirausahaan, serta pelatihan hidup sehat di daerah wisata di masa pandemic virus melalui pembuatan hand sanitizer. Pasca pelatihan, dilakukan survey untuk mengukur kesadaran dan komitmen warga untuk terlibat dan mendukung pembangunan desa wisata, sebagaimana tergambarkan dari tabel berikut:

Tabel 1. Hasil survei

\begin{tabular}{lccccc}
\hline \multicolumn{1}{c}{ Pernyataan } & SS & S & TS & STS & NA \\
\hline Saya yakin Sepahat memiliki potensi desa wisata alam & 84 & 16 & 0 & 0 & 0 \\
Saya yakin potensi Desa Sepahat dapat dikembangkan & 92 & 8 & 0 & 0 & 0 \\
$\begin{array}{l}\text { Saya mendukung pengembangan potensi wisata Desa } \\
\text { Sepahat }\end{array}$ & 76 & 20 & 0 & 0 & 4 \\
Saya tahu tentang desa wisata & 64 & 36 & 0 & 0 & 0 \\
Saya mendukung pembentukan desa wisata di Sepahat & 80 & 20 & 0 & 0 & 0 \\
\hline
\end{tabular}




\begin{tabular}{lccccc}
\hline \multicolumn{1}{c}{ Pernyataan } & SS & S & TS & STS & NA \\
\hline Saya tahu wisata dapat meningkatkan kesejahteraan & 68 & 20 & 0 & 0 & 12 \\
Saya ingin menjadi bagian dari desa wisata & 100 & 0 & 0 & 0 & 0 \\
Saya mendukung pengembangan kuliner khas Sepahat & 76 & 16 & 0 & 0 & 6 \\
Saya mendukung pengembangan kerajinan khas Sepahat & 84 & 8 & 0 & 0 & 8 \\
Saya mendukung pengembangan homestay & 60 & 32 & 0 & 0 & 8 \\
Saya mendukung pembentukan masyarakat Kampung & 76 & 16 & 0 & 0 & 8 \\
Wisata Sepahat (Pokdarwis) & & & & & \\
Saya akan terlibat dalam masyarakat Kampung Wisata & 68 & 28 & 0 & 0 & 4 \\
Sepahat & & & & &
\end{tabular}

Keterangan: $S S=$ Sangat Setuju; $S=$ Setuju; $T S=$ Tidak setuju; STS = Sangat tidak setuju; NA = Tak mengisi

Tabel di atas memberikan gambaran bagaimana pengetahuan dan dukungan masyarakat peserta pelatihan dan pendampingan terhadap gagasan pengembangan desa wisata di wilayah mereka. Seluruh peserta menyatakan ketertarikannya untuk menjadi bagian dari desa wisata dengan menyatakan sangat setuju. Peserta juga menilai potensi yang ada di desa mereka dapat dikembangkan lagi dari kondisi yang ada saat ini, diwakili oleh $92 \%$ peserta sangat setuju dan $8 \%$ setuju. KeyaKinan tersebut diarahkan kepada desa wisata alam. Memang tidak semua peserta menyatakan secara terbuka dukungan atau penolakan terhadap penembangan potensi wisata di desa ini, termasuk sebanyak $12 \%$ peserta enggan menyatakan pengetahuannya terkait dengan dukungan terhadap pengembangan potensi wisata di desanya. Secara umum dapat disimpulkan bahwa masyarakat mendukung pengembangan wisata di desa mereka dan bersedia terlibat dalam kegiatannya.

Kegiatan pendampingan dilakukan terhadap warga pemilik homestay dengan langsung menginap. Ada sejumlah persoalan yang ditemui, mulai dari kebersihan, kerapian, keindahan serta standarisasi. Barang-barang milik pribadi di kamar homestay bukan hanya tidak ditata rapi akan tetapi menumpuk berserakan. Homestay yang ada terkesan kumuh, tidak ditunjang sejumlah fasilitas sederhana yang diperlukan pengunjung seperti lemari, cermin, dan kebersihan alat tidur. Pendampingan ini menghasilkan perubahan tampilan kamar homestay seperti telah tersedianya kamar yang lebih rapi, bersih, serta tiadanya peralatan pemilik homestay di dalam kamar yang disewa. Peralatan penunjang sederhana seperti lemari pakaian dan cermin pun telah tersedia. Perubahan ini terjadi saat kunjungan kedua dilakukan di homestay yang sama. Walaupun begitu, sarana MCK belum menunjukkan perbaikan.

Pendampingan juga dilakukan terhadap pengelola pantai (Bumdes) sebagai destinasi utama wisata di Desa Sepahat yang memiliki dermaga termasuk gerai makanan dan minuman. Ditemukan sejumlah persoalan terkait dengan kenyamanan pengunjung di pantai ini. Mulai dari kebersihan, fasilitas MCK, parkir, akses ke dermaga, ketiadaan fasilitas promosi dan pemasaran terpadu bagi UMKM setempat juga aneka ragam sarana permainan pantai. Perubahan yang ditemui saat kunjungan berikutnya adalah terjadinya perbaikan dan kemudahan akses ke dermaga, peningkatan kebersihan serta tersedianya gerai promosi produk pelaku usaha tempatan.

Ketiga, adalah penguatan kelembagaan masyarakat dan pemerintah desa. Sinergitas yang kuat antara sesama pelaku usaha guna menunjang aktivitas pariwisata di pantai Desa Sepahat dapat diwujudkan dengan adanya wadah pemersatu sebagai tempat untuk mendiskusikan dan memecahkan persoalan yang dihadapi warga secara bersama. Bentuknya adalah Pokdarwis (kelompok sadar wisata). Usulan ini mendapatkan sambutan dukungan berupa diterimanya usulan tim pengabdi berupa draf anggaran dasar Pokdarwis Desa Sepahat. Formalitas Desa Sepahat sebagai desa wisata juga perlu mendapat legalitas guna terjaminnya kepastian hukum dalam membuat dan mengeluarkan berbagai kebijakan di tingkat desa. Draf usulan rancangan peraturan desa (Perdes) dari tim pengabdi juga diterima kepada desa.

Aparat pemerintahan di tingkat kecamatan (Camat Kecamatan Bandar Laksamana) menyatakan dukungannya untuk terwujudnya Desa Wisata Sepahat. Hal ini dinyatakannya di berbagai pelatihan yang diselenggarakan dalam rangka kegiatan pelatihan dan kegiatan penunjang proses pembentukan desa wisata. 
Ada beberapa partisipasi aktif masyarakat yang dilakukan secara mandiri untuk menopang aktivitas wisata desa, seperti pelatihan fotografi oleh fotografer profesional ditujukan kepada generasi muda setempat. Latar pantai Sepahat dijadikan sebagai 'icon; daerah kunjungan baru dan dipromosikan melalui media sosial instagram. Partisipasi dan dukungan masyarakat juga dilakukan dalam bentuk membuat video lagu bertema Melayu dengan latar belakang Pantai Sepahat untuk kemudian dipublikasi di media youtube.

\section{KESIMPULAN}

Pencapaian kegiatan ini dapat dikatakan berhasil mengingat persoalan yang mencuat antara keinginan aparat pemerintah dengan masyarakat yang semula berseberangan kita menjadi sejalan. Hanya saja kegiatan ini belum akan memberikan perubahan secara signifikan terhadap pola kehidupan masyarakat Desa Sepahat. Hal ini dikarenakan persoalan waktu bahwa mengubah pola kebiasaan dan pekerjaan masyarakat kepada sesuatu yang baru tidak dapat dilakukan secara instan dan parsial. Hanya saja peluang desa ini untuk berkembang menjadi desa wisata yang digerakkan dan dimanfaatkan oleh masyarakat secara langsung tetap terbuka lebar. Hanya diperlukan keberlanjutan pendampingan, seperti memperkuat organisasi Pokdarwis melalui pembentukan struktur tetap, aturan organisasi serta pendampingan pembahasan rancangan peraturan desa tentang desa wisata.

Sebagai desa binaan universitas, keberlanjutan kegiatan adalah keniscayaan, maka diperlukan rangkaian kegiatan lanjutan di desa ini seperti memfasilitasi pembuatan website promosi wisata desa dan beragam kuliner serta potensi budaya yang dapat dikembangkan. Selain itu, pendampingan dan tata kelola kawasan wisata, pembuatan peta kawasan wisata serta rancangan pengembangan kawasan wisata demi terwujudnya desa wisata mandiri di Desa Sepahat adalah pekerjaan yang menjadi agenda di waktu selanjutnya.

\section{UCAPAN TERIMA KASIH}

Kegiatan pendampingan pembentukan Desa Wisata Sepahat adalah kegiatan pengabdian kepada masyarakat dan terlaksana atas dukungan dana DIPA LPPM Universitas Riau tahun anggaran 2020. Kami tim pengabdian mengucapkan terima kasih kepada Lembaga Penelitian dan Pengabdian Masyarakat Universitas Riau, begitu juga Kepada Desa Sepahat, Camat Bandar Laksamana, para ahli dari desa wisata dari UI, ITB, USU, Unila, dan IPB serta masyarakat peserta pendampingan atas dukungannya pada kegiatan ini serta mahasiswa yang tergabung dalam Kukerta 2020.

\section{DAFTAR PUSTAKA}

Binilang, R. papiaJ C. F. \& P. H. G. 2018. Pengembangan Kawasan Pesisir Yang Berkelanjutan Di Kabupaten Minahasa Utara. Spasial, 5(2), 141-149.

Fildzah, A., Krisnani, H., \& Darwis, R. S. 2015. Pengembangan Desa Wisata Melalui Konsep Community Based Tourism. Prosiding Penelitian Dan Pengabdian Kepada Masyarakat, 2(3). https://doi.org/10.24198/jppm.v2i3.13581

Hermawan, H. 2017. Dampak Pengembangan Desa Wisata Nglanggeran Terhadap Ekonomi Masyarakat Lokal. III(2), 105-117. https://doi.org/10.31219/osf.io/xhkwv

Sayung, K., \& Demak, K. 2015. Perencanaan Desa Wisata Dengan Pendekatan Konsep Community Based Tourism (CBT) Di Desa Bedono, Kecamatan Sayung, Kabupaten Demak. 1(2), 51-60. https://doi.org/10.14710/ruang.1.2.61-70

Setiawan, B., \& Zulfanita. 2016. Pengembangan Desa Wisata Jatimalang Berbasis Industri Kreatif. Agrokreatif Jurnal Ilmiah Pengabdian Kepada Masyarakat, 1(2), 101. https://doi.org/10.29244/agrokreatif.1.2.101-109 